\title{
PERTANIAN
}

\section{PENGARUH PENAMBAHAN PUPUK KANDANG SAPI DAN PUPUK SP-36 \\ TERHADAP PERBAIKAN SIFAT KIMIA TANAH, PERTUMBUHAN DAN \\ PRODUKSI TANAMAN SORGHUM (Sorghum bicolor L.) PADA TANAH TERCEMAR LIMBAH PADAT PABRIK KERTAS (LIME MUD)}

\author{
The Effect of Cow Manure and Sp-36 Fertilizer on Soil Chemical Improvement, Growth \\ and Sorghum Bicolor L. Production in Polluted Soil (Lime Mud)
}

Afaf Millatusy Syahidah* dan Bambang Hermiyanto

\author{
Program Studi Agroteknologi, Fakultas Pertanian, Universitas Jember \\ Jalan Kalimantan No. 37, Kampus Tegal Boto, Jember 68121 \\ *E-mail: afafmsyahidah@gmail.com
}

\begin{abstract}
Solid waste pollution of Paper manufacturer (Lime mud) can cause land degradation through decreasing soil quality due to chemical, physical and biological properties changes. The purpose of this study was to determine the effect of adding cow manure and SP-36 fertilizer to give improvement in the soil chemical properties, growth and production of Sorghum. Pot experiment was conducted using Randomized block Design (RBD) factorial with two factors, the first factor was soil conditions (polluted and non-polluted soil), the second factor was the type of fertilizer with 4 levels including control, cow manure (258 gram/pot), SP-36 fertilizer (0.64 gram/pot) and combination of cow manure (2658 gram/pot) and SP-36 fertilizer (0.64 gram/pot). The parameter of chemical properties observation included soil $\mathrm{pH}(\mathrm{pH}$ meter), $\mathrm{C}$-organic (Kurmis), Cation Exchange Capacity (extract of ammonium acetate $1 \mathrm{M}$ ph 7), P-availability (Olsen) and Ca-exchanged (extract of ammonium acetate $1 \mathrm{M}$ ph 7). The parameter of the plant growth and production included height of plant, dry weight of plant stem and leave and weight of 1,000 seeds. The research result revealed that combination of manure and SP36 fertilizer to the polluted soil could decrease soil $\mathrm{pH}$ from 8.31 to 8.17 , Ca-exchanged decrease in amount of $49.58 \%$ compared to the control ones, and the increase of P-availability was in amount of $92.89 \%$ compared to the controlled ones. The addition of cow manure to the polluted soil could increase C-organic in amount of $222.7 \%$ and weight of 1,000 seeds increased in amount of $24.9 \%$ compared to the controlled ones. The provision of SP-36 treatment to the polluted soil could increase $\mathrm{CEC}$ of soil in amount of $3.25 \%$ and the height of plant increased to $9.31 \%$ compared to the control ones.
\end{abstract}

Keyword: Manure, SP-36 fertilizer, Sorghum, Chemical Improvement, Lime mud

\section{ABSTRAK}

Pencemaran limbah padat Pabrik Kertas (Lime mud) dapat menyebabkan terjadinya degradasi lahan melalui penurunan kualitas tanah karena perubahan sifatkimia, fisika dan biologi tanah. Tujuan dari penelitian ini adalah untuk mengetahui pengaruh penambahan pupuk kandang sapi dan pupuk SP-36 terhadap perbaikan sifat kimia tanah, pertumbuhan dan produksi tanaman Sorghum pada tanah tercemar limbah padat (Lime mud). Percobaan pot dilakukan menggunakan Rancangan Acak Kelompok (RAK) faktorial dengan dua faktor, faktor pertama kondisi tanah (tanah tidak tercemar dan tanah tercemar), faktor kedua jenis pupuk dengan 4 taraf terdiri atas kontrol, pupuk kandang sapi (258 gram/pot), pupuk SP-36 (0,64 gram/pot) dan kombinasi pupuk kandang sapi (258 gram/pot) dan pupuk SP-36(0,64 gram/pot). Parameter pengamatan sifat kimia tanah meliputi $\mathrm{pH}$ tanah ( $\mathrm{pH}$ meter), C-organik (Kurmis), KTK tanah (ekstrak Amonium asetat $1 \mathrm{M}$ ph 7), Ptersedia (Olsen) dan Ca-tertukar (ekstrak Amonium asetat $1 \mathrm{M}$ ph 7). Parameter pertumbuhan dan produksi tanaman meliputi tinggi tanaman, berat kering brangkasan dan berat 1000 biji. Hasil penelitian menunjukkan kombinasi pupuk kandang dan pupuk SP-36 pada tanah tercemar dapat menurunkan pH tanah dari 8.31 menjadi 8.17, Ca-tertukar menurun sebesar 49,58 \% dibanding kontrol, dan terjadi peningkatan P-tersedia sebesar $92.89 \%$ dibandingkan dengan kontrol. Penambahan pupuk kandang sapi pada tanah tercemar mampu meningkatkan C-organik sebesar $222.7 \%$ dan berat 1000 biji meningkat 24,9\% dibandingkan dengan

kontrol. Pemberian pupuk SP-36 pada tanah tercemar dapat meningkatkan KTK tanah sebesar 3.25\% dan tinggi tanaman meningkat $9.31 \%$ dibanding kontrol.

Kata kunci: Pupuk Kandang Sapi, Pupuk SP-36, Sorghum, Sifat Kimia Tanah, Lime mud

How to citate: Syahidah, A.M., Hermiyanto, B. 2019. Pengaruh Pupuk Kandang Sapid an Pupuk SP-36 terhadap Perbaikan Sifat Kimia Tanah, Pertumbuhan dan Produksi Tanaman Sorghum (Sorghum bicolor) pada Tanah Tercemar Limbah Padat Pabrik Kertas (Lime mud). Berkala Ilmiah Pertanian. 2(3): 132-140.

\section{PENDAHULUAN}

Lime mud merupakan limbah padat yang dihasilkan oleh industri pulp dan kertas selain sludge. Industri pulp dan kertas mengkonversi kembali larutan Natrium hidroksida $(\mathrm{NaOH})$ dan
Sodium sulfida $(\mathrm{Na} 2 \mathrm{~S})$ yang digunakan selama proses pemasakan. Proses pemulihan bahan kimia tersebut meliputi beberapa tahapan, salah satunya yaitu proses kaustisasi dan kalsinasi. Pada proses ini $\mathrm{Na} 2 \mathrm{CO} 3$ dikonversi kembali menjadi $\mathrm{NaOH}$ dengan penambahan kapur $(\mathrm{CaO})$. Proses selanjutnya $\mathrm{CaO}$ bereaksi dengan air 
membentuk kalsium hiroksida $(\mathrm{Ca}(\mathrm{OH}) 2)$. Hasil dari proses kaustisasi tersebut yaitu terbentuknya $\mathrm{NaOH}$ dan kalsium Karbonat $(\mathrm{CaCO} 3)$. Produk kaustisasi yaitu berupa endapan $\mathrm{CaCO} 3$ yang disebut denganLime mud .

Pembuangan limbah padat Lime mud menyebabkan degradasi lahan melalui penurunan kualitas tanah. $\mathrm{Ca}$ dan $\mathrm{Mg}$ yang terdapat pada Lime mud menyebabkan perubahan sifat kimia tanah yaitu meninkatnya $\mathrm{pH}$ dan Ca-terukar tanah sehingga menyebabkan rendahnya P-tersedia dalam tanah. Pada tanah dengan $\mathrm{pH}$ tanah alkali, $\mathrm{P}$ terfiksasi oleh $\mathrm{Ca}$ dan $\mathrm{Mg}$ sehingga ketersediaan P pada larutan tanah berkurang (Armstrong, 1999).

Tingginya $\mathrm{pH}$ tanah menyebabkan hanya beberapa jenis tanaman yang mampu tumbuh di lahan tercemar tersebut, sehingga menurunkan keragaman dan populasi tumbuhan. Kondisi ini berpengaruh terhadap kandungan $\mathrm{C}$-organik tanah,dimana seresah tanaman dan hewan merupakan salah satu sumber C-organik tanah.

Sorghum sebagai salah satu tanaman yang mampu tumbuh di daerah kering memiliki potensi yang besar untuk dikembangkan pada lahan tercemar limbah padat Lime mud, dimana tanaman Sorghum dapat dibudidayakan pada tanah dengan $\mathrm{pH}$ lebih dari 6,5 (Butchee et al, 2012).

Kondisi lahan tercemar limbah padat (lime mud) perlu dilakukan perbaikan tanah melalui peningkatan kualitas tanah, salah satunya dengan penambahan pupuk organik dan pupuk anorganik. Pupuk kandang adalah salah satu pupuk organik yang berasal dari fermentasi kotoran kandang seperti kotoran sapi, kambing atau unggas. Pupuk kandang memiliki sifat yang alami dan tidak merusak serta mampu menyediakan unsur makro (nitrogen, fosfor, kalium, kalsium dan belerang) dan unsur mikro seperti besi, seng, boron, kobalt dan molibdenium.Pupuk SP-36 mampu mensuplai kebutuhan hara phospor dan meningkatkan ketersediaan $\mathrm{P}$ pada tanah. Penelitian ini bertujuan untuk mengetahui pengaruh penambahan pupuk kandang dan pupuk SP36 terhadap perbaikan sifat kimia tanah, pertumbuhan dan produksi Sorghum pada tanah tercemar limbah padat Lime mud.

\section{BAHAN DAN METODE}

Percobaan pot dilaksanakan di Green House Perumahakn Leces Indah desa Banjarsawah, Tegalsiwalan-Probolinggo. Analisis sampel tanah dilaksanakan di Laboratorium Kesuburan dan Pemupukan Jurusan Tanah Fakultas Pertanian Universitas Jember. Waktu penelitian dimulai bulan Maret 2018 hingga Januari 2019.

Alat dan Bahan. Bahan yang digunakan dalam penelitian ini meliputi kotoran kandang, tanah tidak tercemar dan tanah tercemar serta larutan kimia seperti asam sulfat pekat, larutan $\mathrm{K} 2 \mathrm{Cr} 2 \mathrm{O} 71$ $\mathrm{N}$, larutan standar glukosa $5000 \mathrm{ppm}$, campuran selen, asam borat

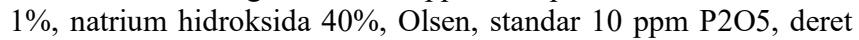
standart, campuran pereaksi sulfat, amonium asetat $\mathrm{pH} 7,00$, Aquades, dan alkohol 96\% Alat yang digunakan yaitu sekop, pisau, karung bekas, erlenmeyer $500 \mathrm{ml}$, gelas ukur, labu Kjeldajl, pipet tetes, Destilator, Spektrofotometer, $\mathrm{Ph}$ Meter, AAS, timbangan analitis, Oven, Hydrometer dan alat tulis.

Rancangan Penelitian. Rancangan percobaan disusun dalam Rancangan Acak Kelompok Faktorial (RAK faktorial). Faktor pertama yaitu kondisi tanah yang terdiri dari dua taraf, $\mathrm{T} 1=$ tanah tidak tercemar dan T2 = tanah tercemar.. Faktor kedua yaitu jenis pupuk yang terdiri dari 4 taraf, $\mathrm{P} 0=$ kontrol, $\mathrm{P} 1=$ pupuk kandang (258 gram/pot), P2 = SP-36 0.64 gram/pot dan P3 = kombinasi pupuk kandang (258 gram/pot) dan pupuk SP-36 (0.64 gram/pot). Terdapat 8 perlakuan dengan 3 kali ulangan dimana terdapat 2 faktor yang diamati sehingga diperoleh 24 kombinasi perlakuan.

Pelaksanaan Penelitian. Pelaksanaan penelitian dilakukan dengan cara melaksanakan beberapa tahapan antara lain:

Tahap Analisis Awal Tanah. Tanah yang digunakan sebagai media penelitian terlebih dahulu dianalisis kandungan $\mathrm{pH}, \mathrm{KTK}$, C-Organik, N, P, K, Ca dan $\mathrm{Mg}$ serta menganalisis tekstur dan Kadar Air Persiapan Media Tanam.

Pembuatan Pupuk Kandang. Tahap-tahap pembuatan pupuk kandang dimulai dari penyiapan bahan berupa kotoran sapi yang diperoleh dari petani setempat. Kotoran sapi tersebut kemudian dimasukkan kedalam karung dan dikomposkan selama 120 hari pada suhu ruang serta kadar air dipertahankan pada kondisi $30 \%$. Setelah proses komposisi selesai maka dilakukan pengujian kandungan hara pada pupuk yang meliputi analisis kadar air, C-organik, N-total, P-tersedia, K, Ca dan Mg.

Persiapan Media tanam. Tahap awal penelitian yaitu menentukan lokasi titik pengambiilan tanah tidak tercemar dan tanah tercemar. Tahap selanjutnya menyiapkan media tanam berupa pot yang berisi $15 \mathrm{~kg}$ tanah sesuai perlakuan kondisi tanah. Pemberian pupuk dasar dilakukan dengan cara menambahkan pupuk Urea 1 gram/Pot (setara dengan $200 \mathrm{Kg} / \mathrm{Ha}$ ) dan $\mathrm{KCl} 0,5$ gram/Pot (setara dengan $100 \mathrm{Kg} / \mathrm{Pot}$ ) pada saat penanaman. Perlakuan pupuk kandang sapi diberikan dua minggu sebelum tanam.

Penanaman. Masing-masing pot ditanami benih Sorghum sebanyak 2 butir biji Sorghum. Satu minggu setelah penanaman, pada masing-masing pot dipilih satu tanaman yang paling baik pertumbuhannya.

Pemeliharaan Tanaman. Pemeliharaan tanaman dilakukan dengan melakukan penyiraman, pengendalian gulma, pengendalian hama dan penyakit. Penyiraman penting dilakukan saat tanaman berumur satu sampai empat minggu setelah tanam. Pengendalian gulma dilakukan secara manual, yaitu dengan cara menyiangi gulma-gulma yang tumbuh di pot. Sedangkan untuk mengatasi hama dan penyakit dipenambahankan pestisida.

Pemanenan. Pemanenan dilakukan pada saat tanaman memasuki fase vegetatif maksimum atau berumur 100-105 HST. Sorghum siap dipanen apabila $80 \%$ dari biji sudah mengeras serta malai telah menguning. Pemanenan dilakukan dengan mencabut cara memangkas tangkai di bawah malai dengan menggunakan sabit. Malai yag telah dipanen kemudian dikeringkan dan dirontokkan dengan alat perontok atau secara manual menggunakan tangan.

Variabel Pengamatan. Parameter pengamatan analisis sifat kimia tanah meliputi $\mathrm{pH}$ tanah, C-organik, KTK, Ptersedia dan Ca-tertukar. Sedangkan parameter pertumbuhan dan produksi tanaman meliputi tinggi tanaman, berat kering tanaman dan berat 1000 biji

\section{HASIL DAN PEMBAHASAN}

\section{Karakteristik Tanah dan Pupuk Kandang yang digunakan}

Analisis pendahuluan dilakukan untuk mengetahui karakteristik dan kandungan hara pada tanah sebelum diberi perlakuan. Kondisi tanah yang digunakan dalam penelitian terdiri atas tanah tercemar dan tanah tidak tercemar. Berdasarkan hasil analisis pendahuluan sifat fisika tanah tercemar didapatkan tekstur tanah liat dengan presentase liat sebesar $78,39 \%$, debu $18,76 \%$ dam pasir 2,85\%. Adapun hasil analisis sifat kimia tanah tercemar disajikan pada Tabel 1 .

$\underline{\text { Tabel 1. Karakteristik Tanah Tercemar Limbah Padat (Lime mud) }}$

\begin{tabular}{lcc}
\hline \multicolumn{1}{c}{ Sifat Kimia } & \multicolumn{2}{c}{ Tanah Tercemar } \\
\cline { 2 - 3 } pH H2O & 8,64 & Kategori* \\
Kadar Air (\%) & 11,6 & Alkalis \\
C-Organik (\%) & 0,74 & Sangat Rendah \\
KTK (me/100 g) & 53,6 & Sangat Tinggi \\
N-total (\%) & 0,032 & Sangat Rendah \\
P-tersedia (ppm) & 3,45 & Sangat Rendah \\
K-tertukar (me/100 g) & 0,53 & Sedang \\
Ca-tertukar (me/100 g) & 15,048 & Tinggi \\
Mg-tertukar (me/100 g) & 3,10 & Tinggi \\
Tekstur & & Liat \\
Pasir (\%) & 2,85 & \\
Debu (\%) & 18,76 & \\
Lempung (\%) & 78,39 & \\
* Berdasarkan Penilaian & Analisis Tanah, Kriteria Hasil Balai \\
Penelitian Tanah (2009) & &
\end{tabular}


Pada tanah tercemar $\mathrm{pH}$ tanah tergolong alkalis disebabkan karena tanah yang digunakan dalam penelitian berasal dari lahan yang terkena dampak dari limbah Pabrik Kertas. Limbah yang dihasilkan oleh Pabrik Kertas berupa lumpur kapur atau yang disebut dengan Lime mud. Lime mud merupakan produk sampingan berupa limbah padat kapur yang dihasilkan dari proses pemulihan bahan kimia dimana Lime mud mengandung 95\% Kalsium Karbonat (CaCO3). Karakteristik limbah padat Lime mud disajikan pada tabel berikut.

Tabel 2. Karakteristik Limbah padat Lime mud

\begin{tabular}{lccc}
\hline Sifat Kimia & Satuan & Nilai & Keterangan* \\
\hline pH H2O & - & 10,55 & Alkalis \\
Ca-tertukar & me/100 g tanah & 97,56 & Sangat Tinggi \\
Mg-tertukar & me/100 g tanah & 3,77 & Tinggi \\
C-Organik & $\%$ & 0,0206 & Sangat Rendah \\
Na-tertukar & $\%$ & 0,148 & Rendah \\
\hline
\end{tabular}

*) Berdasarkan Kriteria Penilaian Hasil Analisis Tanah, Balai Penelitian Tanah (2009)

Selain tanah tercemar, penelitian ini juga menggunakan tanah tidak tercemar sebagai pembanding. Tanah tidak tercemar yang digunakan dalam penelitian merupakan tanah yang ridak terkena dampak limbah padat Lime Mud. Tanah tidak tercemar memiliki karakteristik seperti tanah Inceptisol pada umumnya. Hasil analisis kimia tanah tidak tercemar disajikan pada tabel berikut.

Tabel 3. Karakteristik Tanah Tidak Tercemar

\begin{tabular}{|c|c|c|}
\hline \multirow[t]{2}{*}{ Sifat Kimia } & \multicolumn{2}{|c|}{ Tanah Tidak Tercemar } \\
\hline & Kadar & Kategori* \\
\hline $\mathrm{pH} \mathrm{H} 2 \mathrm{O}$ & 6,61 & Netral \\
\hline Kadar Air (\%) & 12,4 & - \\
\hline C-Organik (\%) & 3,89 & Tinggi \\
\hline $\mathrm{KTK}(\mathrm{me} / 100 \mathrm{~g})$ & 58,0 & Sangat Tinggi \\
\hline N-total (\%) & 0,095 & Sangat Rendah \\
\hline P-tersedia (ppm) & 12,10 & Sedang \\
\hline K-tertukar (me/100 g) & 3,35 & Sangat Tinggi \\
\hline Ca-tertukar (me/100 g) & 8,846 & Sedang \\
\hline Mg-tertukar (me/100 g) & 0,89 & Rendah \\
\hline Tekstur & & Lempung Berdebu \\
\hline Pasir (\%) & 19,62 & \\
\hline Debu (\%) & 60,93 & \\
\hline Lempung (\%) & 19,45 & \\
\hline
\end{tabular}

*) Berdasarkan Kriteria Penilaian Hasil Analisis Tanah, Balai Penelitian Tanah (2009)

Bahan organik merupakan salah satu bahan pembenah tanah yang dapat memperbaiki sifat-sifat tanah baik sifat fisik, kimia dan biologi tanah. Bahan organik yang digunakan dalam penelitian ini adalah pupuk kandang sapi. Pupuk kandang sapi mengandung bahan organik serta beberapa unsur hara sehingga dapat memperbaiki sifat-sifat tanah. Pupuk kandang yang digunakan dalam penelitian mengandung C-Organik tinggi yaitu 44,55\%. Nilai C-Organik pada pupuk kandang tersebut telah memenuhi standart pupuk organik berdasarkan Kementerian Pertanian tahun 2009. Hasil analisis sifat kimia pupuk kandang sapi disajikan pada Tabel 8 berikut.

Tabel 4. Analisis Sifat Kimia Pupuk Kandang Sapi

\begin{tabular}{lccc}
\hline Sifat Kimia & Satuan & Nilai & Keterangan* \\
\hline C-Organik & $\%$ & 4,55 & Memenuhi syarat \\
N-total & $\%$ & 1,8 & Belum memenuhi syarat \\
C/N & - & 24,72 & Memenuhi syarat \\
K-tertukar & $\mathrm{me} / 100 \mathrm{~g}$ & 1,03 & Belum memenuhi syarat \\
P-tersedia & $\&$ & 0,17 & Belum memenuhi syarat \\
Ca-tertukar & $\mathrm{me} / 100 \mathrm{~g}$ & 0,42 & - \\
Mg-tertukar & $\mathrm{me} / 100 \mathrm{~g}$ & 0,54 & - \\
\hline
\end{tabular}

*) Berdasarkan Persyaratan Teknis Minimal Pupuk Organik dan Pembenah Tanah (2009)
Berdasarkan tabel diatas $\mathrm{C} / \mathrm{N}$ rasio pupuk kandang sapi yang digunakan telah memenuhi syarat yaitu sebesar 24,72 . C/N rasio memenuhi syarat pada nilai $15-2,5$ dimana pada rasio nilai tersebut pupuk dapat telah mengalami proses dekomposisi dan mineral yang terdapat pada pupuk kandang telah teserdia dalam bentuk yang dapat diserap tanaman.

\section{Pengaruh Kondisi Tanah dan Jenis Pupuk terhadap Sifat Kimia Tanah}

Hasil selidikragam (ANOVA) parameter pengamatan sifat kimia tanah disajikan dalam tabel 5 berikut.

Tabel 5. Hasil ANOVA Parameter Sifat Kimia Tanah

\begin{tabular}{lccc}
\hline \multirow{3}{*}{$\begin{array}{c}\text { Parameter } \\
\text { Pengamatan }\end{array}$} & $\begin{array}{c}\text { Kondisi } \\
\text { Tanah (T) }\end{array}$ & $\begin{array}{c}\text { Jenis } \\
\text { Pupuk (P) }\end{array}$ & $\begin{array}{c}\text { Interaksi Kondisi } \\
\text { Tanah dan Jenis } \\
\text { Tanah (T x P) }\end{array}$ \\
\hline pH Tanah & $416,09^{* *}$ & $11,87^{* *}$ & $3,17^{\text {ns }}$ \\
KTK Tanah & $1958,91^{* *}$ & $6.08^{* *}$ & $3,64^{*}$ \\
C-Organik & $310,63^{* *}$ & $3,38^{*}$ & $2,58^{\text {ns }}$ \\
P-tersedia & $2931.43^{* *}$ & $32,28^{* *}$ & $12,98^{* *}$ \\
Ca-tertukar & $63,26^{* *}$ & $1,49^{\text {ns }}$ & $59.20^{* *}$ \\
\hline
\end{tabular}

Keterangan : ** berbeda sangat nyata; $*$ berbeda nyata; ${ }^{\mathrm{ns}}$ berbeda tidak nyata

Faktor tunggal kondisi tanah berpengaruh nyata terhadap semua parameter sifat kimia tanah meliputi $\mathrm{pH}$ tanah, KTK tanah, C-organik, P-tersedia dan Ca-tertukar. Sedangkan faktor tunggal jenis pupuk berpengaruh nyata terhadap $\mathrm{pH}, \mathrm{KTK}, \mathrm{C}$ - organik dan P-tersedia. Adapun interaksi dari faktor jenis pupuk dan kondisi tanah tanam berpengaruh nyata terhadap KTK, P-tersedia dan $\mathrm{Ca}^{-}$ tertukar.

pH Tanah

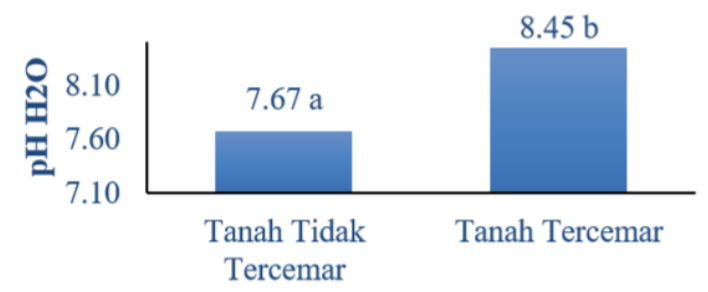

Kondisi Tanah

Gambar 1. Pengaruh Kondisi tanah Terhadap pH Tanah Keterangan: Angka yang diikuti huruf yang berbeda menunjukkan perbedaan yang nyata menurut Uji DMRT pada taraf kepercayaan $5 \%$

Berdasarkan Gambar 1 diketahui bahwa faktor kondisi tanah berpengaruh nyata terhadap $\mathrm{pH}$ tanah sebagai faktor tunggal. Tanah tercemar memiliki nilai rata-rata $\mathrm{pH}$ yang lebih tinggi jika dibandingkan dengan $\mathrm{pH}$ pada tanah tidak tercemar yaitu 8.45, sedangkan nilai rata-rata $\mathrm{pH}$ pada tanah tidak tercemar yaitu 7,67. Perbedaan nilai $\mathrm{pH}$ tanah tersebut disebabkan karena adanya bahan pencemar limbah padat Lime mud pada tanah tercemar (T2).

Faktor jenis pupuk berpengaruh nyata terhadap $\mathrm{pH}$ tanah sebagai faktor tunggal seperti yang disajikan pada gambar berikut:

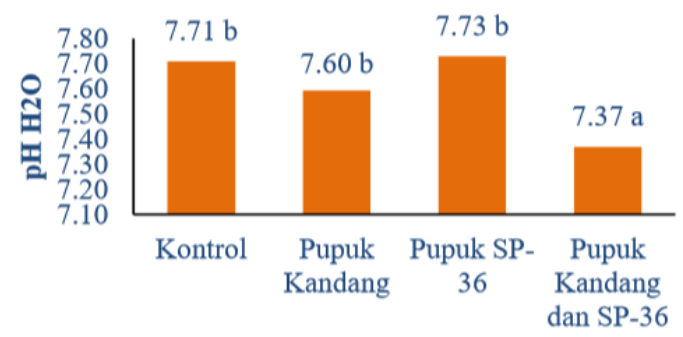

(a) Tanah Tidak Tercemar 


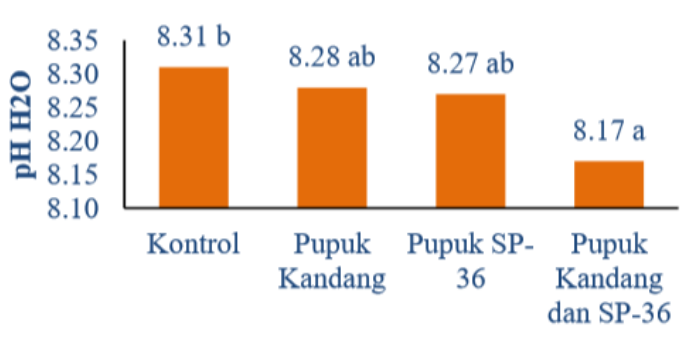

(b) Tanah Tercemar

Gambar 2. Pengaruh Jenis Pupuk Terhadap pH Tanah pada (a)Tanah tidak tercemar dan (b) Tanah Tercemar Keterangan: Angka yang diikuti huruf yang berbeda menunjukkan perbedaan yang nyata menurut Uji DMRT pada taraf kepercayaan 5\%.

Penambahan jenis pupuk mampu menurunkan $\mathrm{pH}$ pada tanah tercemar (T2), namun terjadi peningkatan $\mathrm{pH}$ pada tanah tidak tercemar (T1). Penambahan beberapa jenis pupuk meningkatkan $\mathrm{pH}$ pada tanah tidak tercemar (Gambar 2 a), dimana $\mathrm{pH}$ tertinggi terdapat pada perlakuan pupuk SP-36 (T1P2) yaitu 7,73, penambahan pupuk kandang (T1P1) dapat meningkatkan pH tanah menjadi 7,60, adapun perlakuan kombinasi dari pupuk kandang dan pupuk SP-36 menyebabkan perubahan $\mathrm{pH}$ tanah menjadi 7,37.

Penambahan jenis pupuk mampu menurunkan $\mathrm{pH}$ pada tanah tercemar seperti yang ditunjukkan pada Gambar 2 (b). Penambahan kombinasi pupuk kandang dan pupuk SP-36 pada tanah tercemar (T2P3) mampu menurunkan $\mathrm{pH}$ tanah sebesar $1.68 \%$ dibanding perlakuan Kontrol (T2P0) yaitu terjadi peurunan $\mathrm{pH}$ tanah dari 8.31 menjadi 8.17. Sedangkan penambahan pupuk kandang (T2P1) dan pupuk SP-36 (T2P2) menunjukkan hasil berbeda tidak nyata dibanding dengan perlakuan kontrol.

\section{KTK Tanah}

Jumlah Total Kation yang dapat dipertukarkan pada permukaan koloid bermuatan negatif ini disebut sebagai KapasitasTukar Kation (KTK). Nilai KTK dinyatakan dalam $\mathrm{mg} / 100 \mathrm{~g}$ tanah. Hasil penelitian menunjukkan adanya interaksi antara faktor kondisi tanah dengan jenis pupuk seperti yang disajikan pada gambar berikut.

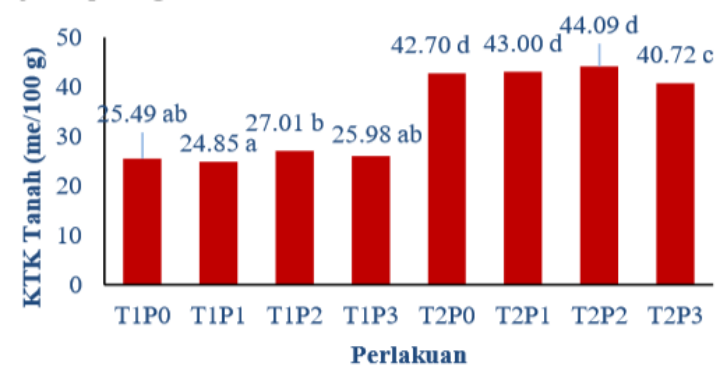

Gambar 3. Pengaruh Perlakuan terhadap KTK tanah Keterangan

T1P0 = Tanah tidak tercemar

T1P1 = Tanah tidak tercemar + Pupuk kandang 258 gram $/$ pot

T1P2 = Tanah tidak terceamr + Pupuk SP-36 $0.64 \mathrm{gram} /$ pot

T1P3 = Tanah tidak tercemar + Pupuk kandang 258 gram $/$ pot dan Pupuk SP-36 0.64 gram/pot

$\mathrm{T} 2 \mathrm{P} 0=$ Tanah tercemar

$\mathrm{T} 2 \mathrm{P} 1=$ Tanah tercemar + Pupuk Kandang 258 gram/pot

$\mathrm{T} 2 \mathrm{P} 2=$ Tanah tercemar + Pupuk SP-36 $0.64 \mathrm{gram} / \mathrm{pot}$

T2P3 = Tanah tercemar + Pupuk Kandang 258 gram $/$ pot dan Pupuk SP-36 0.64 gram/pot

Angka yang diikuti huruf yang berbeda menunjukkan perbedaan yang nyata menurut Uji DMRT pada taraf kepercayaan 5\%

Interaksi kedua faktor menunjukkan berbeda nyata dimana nilai KTK tertinggi terdapat pada perlakuan (T2P2) yaitu 44.09 me/100 gram. Perlakuan T2P0, T2P1 dan T2P2 menunjukkan hasil yang tidak berbeda nyata, ini menunjukkan penambahan pupuk kandang maupun pupuk SP-36 secara tunggal mampu meningkatkan KTK tanah dengan nilai yang tidak berbeda nyata dengan kontrol.

\section{C-Organik}

Pengukuran kandungan C-organik tanah merupakan salah satu indikator kesuburan tanah, dimana nilai C-organik menggambarkan kandungan bahan organik dalam tanah. Bahan organik merupakan salah satu sumber nutrisi bagi tanaman. Faktor kondisi tanah berpengaruh nyata terhadap C-organik tanah seperti yang disajikan pada gambar berikut.

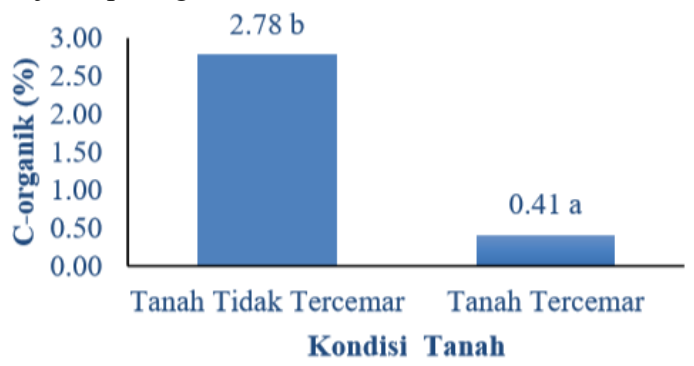

Gambar 4 Pengaruh Kondisi tanah terhadap C-organik Tanah Keterangan: Angka yang diikuti huruf yang berbeda menunjukkan perbedaan yang nyata menurut Uji DMRT pada taraf kepercayaan $5 \%$

Berdasarkan gambar diatas diketahui bahwa faktor kondisi tanah berpengaruh secara nyata terhadap kandungan C- organik, dimana perlakuan tanah tidak tercemar (T1) memiliki kandungan C-Organik lebih tinggi jika dibanding dengan tanah tidak tercemar, dimana nilai rata-rata $\mathrm{C}$-organik pada tanah tercemar hanya $0.41 \%$.

Faktor jenis pupuk tidak berpengaruh nyata terhadap kadar C-organik pada tanah tidak tercemar (T1) namun berpengaruh nyata pada C-organik tanah tercemar (T2) seperti yang ditunjukkan pada gambar berikut:

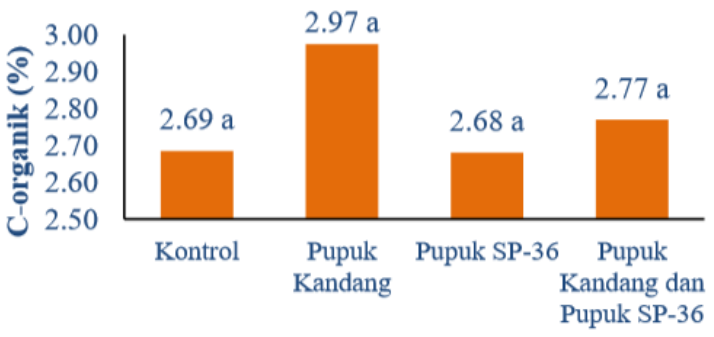

(a) Tanah Tidak Tercemar

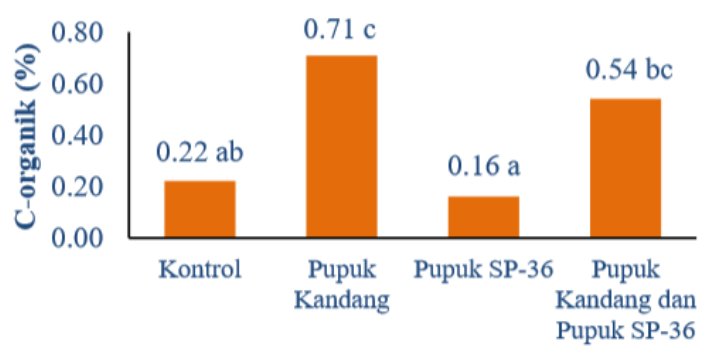

(b) Tanah Tercemar

Gambar 5. Pengaruh Jenis Pupuk Terhadap C-organik pada (a) Tanah tidak tercemar dan (b) Tanah Tercemar Keterangan: Angka yang diikuti huruf yang berbeda menunjukkan perbedaan yang nyata menurut Uji DMRT pada taraf kepercayaan 5\%.

Penambahan pupuk kandang pada tanah tercemar (T2P1) mampu meningkatkan kandungan C-organik hingga 222.73\%. Pupuk kandang merupakan pupuk organik dimana dekomposisi bahan organik akan meningkatkan ketersediaan C-organik dalam tanah. Adapun penambahan jenis pupuk pada tanah tidak tercemar tidak menunjukkan adanya perbedaan yang nyata terhadap kandungan C-organik tanah, hal ini dikarenakan tanah tidak tercemar memilki kandungan C-organik awal yang tinggi, sehingga penambahan beberapa jenis pupuk tidak munjukkan adanya pengaruh yang nyata. 


\section{P-tersedia}

Unsur hara P merupakan salah satu unsur hara esensial yang dibutuhkan tanaman untuk memperkuat perakaran tanaman, proses transfer energi, proses fotosintesis, metabolisme dan respirasi. Interaksi antara kondisi tanah dengan jenis pupuk menunjukkan pengaruh yang nyata terhadap kandungan P-tersedia tanah seperti yang disajikan pada Gambar 6 .

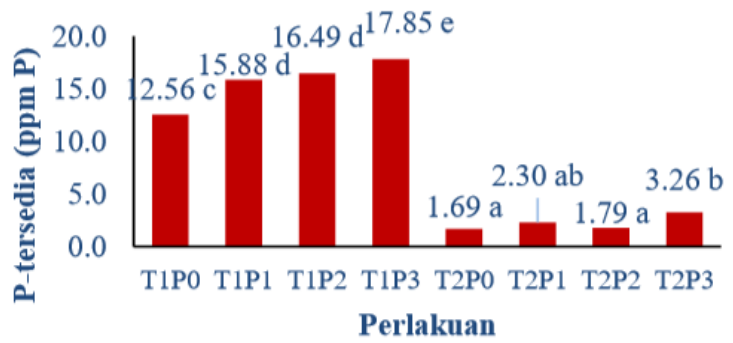

Gambar 6. Pengaruh Perlakuan terhadap P-tersedia tanah Keterangan:

$\mathrm{T} 1 \mathrm{P} 0=$ Tanah tidak tercemar

$\mathrm{T} 1 \mathrm{P} 1=$ Tanah tidak tercemar + Pupuk kandang $258 \mathrm{gram} /$ pot

$\mathrm{T} 1 \mathrm{P} 2=$ Tanah tidak terceamr + Pupuk SP-36 0.64 gram/pot

$\mathrm{T} 1 \mathrm{P} 3=$ Tanah tidak tercemar + Pupuk kandang $258 \mathrm{gram} /$ pot dan Pupuk SP-36 0.64 gram/pot

$\mathrm{T} 2 \mathrm{P} 0=$ Tanah tercemar

$\mathrm{T} 2 \mathrm{P} 1=$ Tanah tercemar + Pupuk Kandang $258 \mathrm{gram} /$ pot

$\mathrm{T} 2 \mathrm{P} 2=$ Tanah tercemar + Pupuk SP-36 0.64 gram $/$ pot

$\mathrm{T} 2 \mathrm{P} 3=$ Tanah tercemar + Pupuk Kandang 258 gram $/$ pot dan Pupuk SP-36 0.64 gram/pot

Angka yang diikuti huruf yang berbeda menunjukkan perbedaan Angka yang diikuti huruf yang berbeda menunjukkan perbedaan yang nyata menurut Uji DMRT pada taraf kepercayaan 5\%

Berdasarkan Gambar 6 diketahui bahwa kadar P-tersedia tertinggi pada tanah tercemar terdapat pada perlakuan kombinasi pupuk kandang dan pupuk SP-36 (T2P3). Penambahan kombinasi pupuk kandang dan SP-36 pada tanah tercemar mampu meningkatkan P-tersedia sebesar $92.90 \%$ jika dibanding Kontrol, adapun penambahan pupuk kandang (T2P1) mampu meningkatkan P-tersedia sebesar $36.09 \%$, sedangkan penambahan pupuk SP-36 hanya mampu meningkatkan P-tersedia sebanyak $5.91 \%$.

\section{Ca-tertukar}

Interaksi kedua faktor menunjukkan hasil yang berbeda nyata terhadap nilai Ca-tertukar. Nilai Ca-tertukar tertinggi terdapat pada perlakuan T2P0 yaitu 11.98 me/100 gram. Tingginya kadar $\mathrm{Ca}$ pada tanah tercemar disebabkan oleh kontaminasi Lime mud. Penambahan pupuk kandang dan SP-36 pada tanah tercemar (T2P3) mampu menurunkan kadar Ca tanah sebesar $49.58 \%$ jika dibanding dengan perlakuan kontrol (T2P0). Pengaruh perlakuan terhadap Ca-tertukar tanah disajikan pada gambar 7.

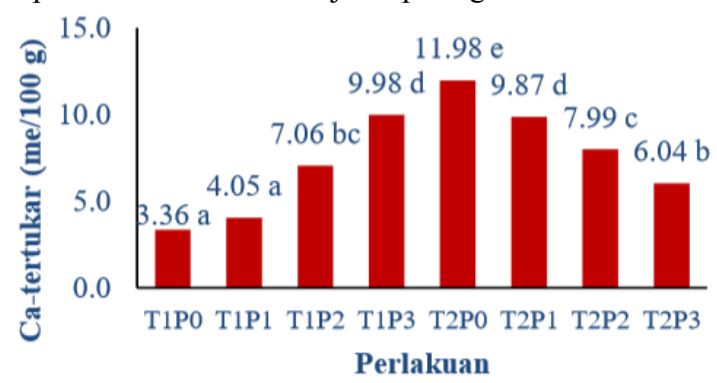

Gambar 7. Pengaruh Perlakuan terhadap Ca-tertukar tanah

Keterangan:

$\mathrm{T} 1 \mathrm{P} 0=$ Tanah tidak tercemar

$\mathrm{T} 1 \mathrm{P} 1=$ Tanah tidak tercemar + Pupuk kandang $258 \mathrm{gram} /$ pot

$\mathrm{T} 1 \mathrm{P} 2=$ Tanah tidak terceamr + Pupuk SP-36 0.64 gram $/$ pot

$\mathrm{T} 1 \mathrm{P} 3=$ Tanah tidak tercemar + Pupuk kandang $258 \mathrm{gram} /$ pot dan Pupuk SP-36 0.64 gram/pot

$\mathrm{T} 2 \mathrm{P} 0=$ Tanah tercemar

$\mathrm{T} 2 \mathrm{P} 1=$ Tanah tercemar + Pupuk Kandang 258 gram $/$ pot
$\mathrm{T} 2 \mathrm{P} 2=$ Tanah tercemar + Pupuk SP-36 0.64 gram $/$ pot

$\mathrm{T} 2 \mathrm{P} 3=$ Tanah tercemar + Pupuk Kandang 258 gram/pot dan Pupuk SP-36 0.64 gram/pot

Angka yang diikuti huruf yang berbeda menunjukkan perbedaan yang nyata menurut Uji DMRT pada taraf kepercayaan 5\%

Pengaruh Kondisi Tanah dan Jenis Pupuk terhadap Pertumbuhan dan Produksi Tanaman Sorghum

Penambahan jenis pupuk pada kondisi tanah yang berbeda bertujuan untuk mengetahui perbaikan beberapa sifat kimia tanah. Pertumbuhan dan produksi sorghum erat kaitannya dengan ketersediaan unsur hara dalam tanah, sehingga penambahan jenis pupuk berpengaruh terhadap pertumbuhan tanaman. Hasil analisis sidik ragam (ANOVA) parameter pertumbuhan dan produksi tanaman Sorghum disajikan pada Tabel 10.

Tabel 10. Hasil ANOVA Parameter Pertumbuhan dan Produksi Tanaman Sorghum

\begin{tabular}{lccc}
\hline \multirow{2}{*}{$\begin{array}{l}\text { Parameter } \\
\text { Pengamatan }\end{array}$} & $\begin{array}{c}\text { Kondisi } \\
\text { tanah }(\mathrm{T})\end{array}$ & $\begin{array}{c}\text { Jenis } \\
\text { Pupuk (P) }\end{array}$ & $\begin{array}{c}\text { Interaksi } \\
\text { T x P }\end{array}$ \\
\hline Tinggi Tanaman & $0.54^{\text {ns }}$ & $7.57^{* *}$ & $1.31^{\text {ns }}$ \\
Berat Kering & $38.83^{* *}$ & $1.26^{\text {ns }}$ & $0.995^{\text {ns }}$ \\
Brangkasan & $46.59^{* *}$ & $3.00^{\text {ns }}$ & $5.83^{* *}$
\end{tabular}

Keterangan : ** berbeda sangat nyata; * berbeda nyata; ns berbeda tidak nyata

Berdasarkan diatas diketahui bahwa perlakuan kondisi tanah tanam berpengaruh nyata sebagai faktor tunggal terhadap berat kering brangkasan dan berat 1000 biji. Adapun perlakuan jenis pupuk berpengaruh nyata terhadap tinggi tanaman. Interaksi faktor kondisi tanah dan jenis pupuk hanya berpengaruh terhadap berat 1000 biji.

\section{Tinggi tanaman}

Tinggi tanaman merupakan salah satu parameter pertumbuhan yang dipengaruhi oleh ketersediaan hara pada fase vegetatif hingga generative. Unsur hara salah satunya dibutuhkan tanaman dalam proses pembelahan sel serta metabolisme tubuh tanaman. Ketersediaan unsur hara memegang peranan penting dalam pembentukan sel dan organ tanaman dimana tinggi tanaman sebagian besar terjadi pada masa vegetatif. Faktor jenis pupuk terhadap pertumbuhan tinggi tanaman disajikan pada Gambar 8 .

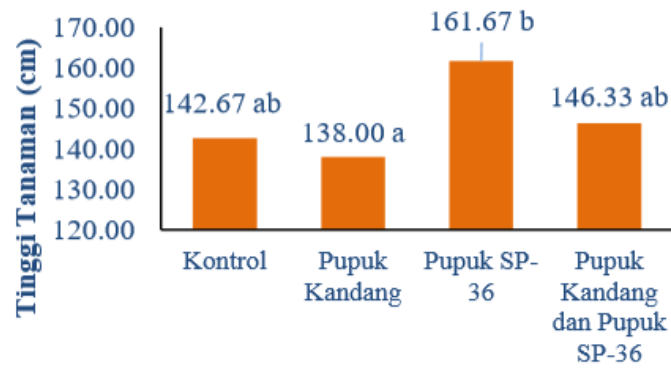

(a) Tanah Tidak Tercemar

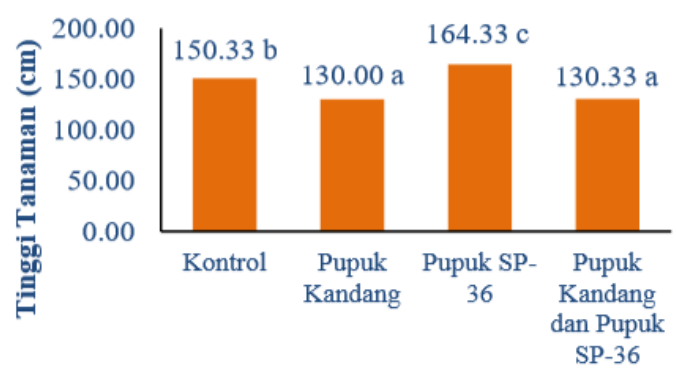

(b) Tanah Tercemar

Gambar 8. Pengaruh Jenis Pupuk Terhadap Tingi Tanaman pada (a) Tanah tidak tercemar dan (b) Tanah Tercemar 
Keterangan: Angka yang diikuti huruf yang berbeda menunjukkan perbedaan yang nyata menurut Uji DMRT pada taraf kepercayaan 5\%

Pada Gambar 8 tinggi tanaman pada tanah tidak tercemar dengan perlakuan penambahan pupuk SP-36 (T1P2) menunjukkan nilai teringgi yaitu $161.67 \mathrm{~cm}$, sama halnya pada perlakuan pupuk SP-36 di tanah tercemar (T2P2) menunjukkan hasil tertinggi yaitu $164.33 \mathrm{~cm}$ kemudian di ikuti oleh perlakuan kontrol (T2P0) dengan tinggi tanaman $150.33 \mathrm{~cm}$. Tinggi tanaman terendah ditunjukkan oleh perlakuan T2P3 yaitu $130.33 \mathrm{~cm}$ dan perlakuan T2P1 dengan tinggi tanaman $130 \mathrm{~cm}$.

\section{Berat Kering Brangkasan}

Berat kering tanaman merupakan indikator dari banyaknya unsur hara yang diserap oleh tanaman. Nilai berat kering tanaman dipengaruhi oleh kandungan hara tersedia dalam tanah. Kondisi tanah yang berbeda menunjukkan hasil yang berbeda nyata terhadap berat kering brangkasan tanaman dimana nilai rata-rata berat kering brangkasan pada kondisi tanah tanah tercemar lebih rendah jika dibanding dengan nilai rata-rata berat kering brangkasan pada tanah tidak tercemar. Faktor kondisi tanah terhadap berat kering brangkasan disajikan pada Gambar 9 .

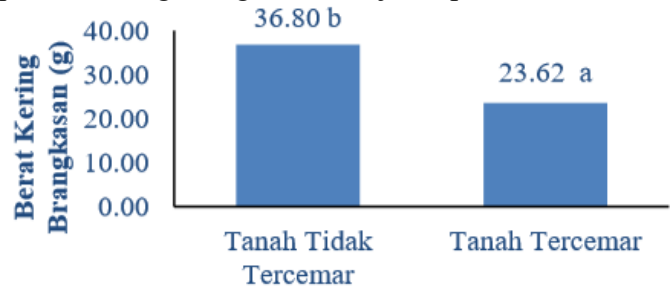

Jenis Media

Gambar 9. Pengaruh Kondisi Tanah terhadap Berat Kering Brangkasan

Keterangan: Angka yang diikuti huruf yang berbeda menunjukkan perbedaan yang nyata menurut Uji DMRT pada taraf kepercayaan $5 \%$

\section{Berat 1000 Biji}

Interaksi faktor kondisi tanah dan jenis pupuk berpengaruh nyata terhadap nilai berat 1000 biji dimana nilai berat 1000 biji tertinggi terdapat pada perlakuan pupuk SP-36 (T1P2). Pada kondisi tanah tercemar, penambahan pupuk kandang (T2P1) mampu meningkatkan berat 1000 biji hingga $24.93 \%$ jika dibanding dengan perlakuan kontrol (T2P0). Pengaruh perlakuan terhadap berat 1000 biji tanaman Sorghum

disajikan pada Gambar 10.

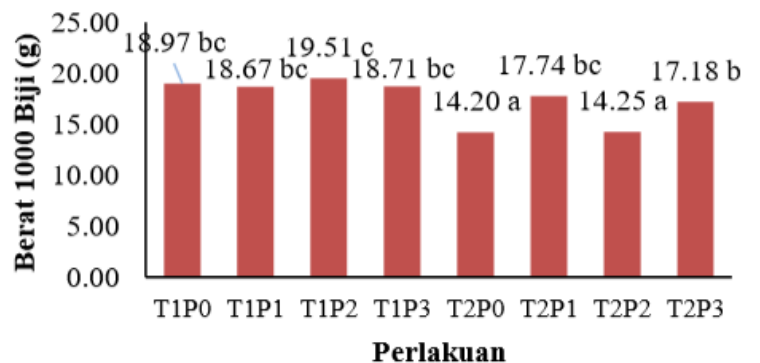

Gambar 10. Pengaruh Perlakuan terhadap Berat 1000 Biji

Keterangan:

$\mathrm{T} 1 \mathrm{P0}=$ Tanah tidak tercemar

$\mathrm{T} 1 \mathrm{P} 1=$ Tanah tidak tercemar + Pupuk kandang $258 \mathrm{gram} /$ pot

$\mathrm{T} 1 \mathrm{P} 2=$ Tanah tidak terceamr + Pupuk SP-36 0.64 gram $/$ pot

$\mathrm{T} 1 \mathrm{P} 3=$ Tanah tidak tercemar + Pupuk kandang $258 \mathrm{gram} /$ pot dan Pupuk SP-36 0.64 gram/pot

$\mathrm{T} 2 \mathrm{P} 0=$ Tanah tercemar

$\mathrm{T} 2 \mathrm{P} 1=$ Tanah tercemar + Pupuk Kandang 258 gram $/$ pot

$\mathrm{T} 2 \mathrm{P} 2=$ Tanah tercemar + Pupuk SP-36 $0.64 \mathrm{gram} / \mathrm{pot}$

$\mathrm{T} 2 \mathrm{P} 3=$ Tanah tercemar + Pupuk Kandang 258 gram $/$ pot dan Pupuk SP-36 0.64 gram/pot

Angka yang diikuti huruf yang berbeda menunjukkan perbedaan yang nyata menurut Uji DMRT pada taraf kepercayaan 5\%
Lumpur kapur atau Lime mud merupakan produk sampingan yang dihasilkan dari proses produksi pulp dan kertas. Sebagai produk sampingan dari industri pulp dan kertas, Lime mud sangat sulit untuk dikeringkan karena memiliki ukuran partikel yang kecil, sehingga banyak pabrik kertas yang memiliki tempat pembuangan untuk limbah tersebut. Namun pembuangan Lime mud pada lahan pembuangan berdampak pada penurunan kualitas tanah. Berdasarkan hasil analisis kimia yang dilakukan oleh Gaskin et al (2017) diketahui bahwa Lime mud tidak mengandung kontaminan berbahaya seperti logam berat, namun kandungan $\mathrm{Ca}$ dan $\mathrm{Mg}$ yang tinggi pada Lime mud mempengaruhi kenaikan $\mathrm{pH}$ tanah. Reaksi $\mathrm{CaO}$ dengan air akan membetuk $\mathrm{Ca}(\mathrm{OH}) 2$ yang selanjutnya terurai menjadi ion $\mathrm{Ca}$ dan $\mathrm{OH}$ - Meningkatnya ion $\mathrm{OH}-$ inilah yang berperan dalam peningkatan $\mathrm{pH}$ tanah (Maryati, 2014).

Peningkatan kadar $\mathrm{Ca}$ akibat pembuangan limbah padat Lime mud selain meningkatkan $\mathrm{pH}$ juga dapat menurunkan P-tersedia, hal ini dikarenakan $\mathrm{P}$ terikat dengan $\mathrm{Ca}$ menjadi kalsium trifosfat (Ca3(PO4)2) (Hanafiah, 2014). Berdasarkan hasil penelitian yang telah dilakukan, faktor kondisi tanah dan jenis pupuk berpengaruh nyata terhadap nilai $\mathrm{pH}$ tanah sebagai faktor tunggal. Tanah tercemar memiliki nilai rata-rata $\mathrm{pH}$ yang lebih tinggi jika dibandingkan dengan $\mathrm{pH}$ pada tanah tidak tercemar. Tanah tercemar (T2) yang digunakan berasal dari lahan yang terkena dampak limbah padat Lime mud, sehingga $\mathrm{pH}$ tanah tercemar meningkat dampak dari meningkatnya kandungan $\mathrm{Ca}$ dan $\mathrm{Mg}$ dari limbah padat Lime mud. Adapun tanah tidak tercemar (T1) merupakan tanah normal yang tidak terkena dampak dari limbah padat Lime mud. Tanah tidak tercemar yang digunakan memiliki ciri sebagaimana jenis tanah Inceptisol pada umumnya.

Faktor jenis pupuk berpengaruh nyata terhadap nilai $\mathrm{pH}$ tanah dimana terjadi peningkatan $\mathrm{pH}$ pada tanah tidak tercemar, namun sebaliknya terjadi penurunan $\mathrm{pH}$ tanah tercemar. $\mathrm{PH}$ pada kondisi tanah tidak tercemar mengalami peningkatan salah satunya disebabkan oleh tingginya kadar bahan organik dalam tanah. Proses dekomposisi bahan organik dapat meningkatkan $\mathrm{pH}$ tanah, hasil akhir sederhana dari perombakan bahan organik antara lain kationkation basa seperti $\mathrm{Ca}, \mathrm{Mg}, \mathrm{K}$ dan $\mathrm{Na}$. Pelepasan kation-kation tersebut ke dalam larutan tanah menyebabkan tanah jenuh dengan kation tersebut dan meningkatkan $\mathrm{pH}$ tanah (Nazari, 2012). Selain itu hasil dekomposisi bahan organik berupa gugus karboksil $(\mathrm{COOH})$ dan hidroksil $(\mathrm{OH})$, dimana semakin meningktanya ion OH- dapat meningkatkan $\mathrm{pH}$ tanah (Siregar, 2017).

Penurunan $\mathrm{pH}$ tanah tercemar salah satunya disebabkan oleh asam organik hasil dekomposisi bahan organik dan eksudat akar. Eksudat akar merupakan senyawa kimia yang dihasilkan oleh akar berupa senyawa-senyawa organik, gula, asam amino, lemak, kumarin, flavoid, protein, enzim, alipatik dan aromatic. Asam organik merupakan salah satu senyawa kimia dari eksudat akar yang berperan dalam menyediakan substrat untuk metabolisme mikroba. Aktivitas respirasi dari mikroba akan mengeluarkan gas $\mathrm{CO} 2$, dimana gas $\mathrm{CO} 2$ jika terakumulasi dapat bereaksi dengan air membentuk asam karbonat ( $\mathrm{H} 2 \mathrm{CO} 3)$ yang meskipun merupakan asam lemah, namun jika terakumulasi akan terurai menjadi HC3dan $\mathrm{H}+$ yang dapat mengasamkan tanah (Hanafiah, 2014).

Kapasitas Tukar Kation (KTK) adalah jumlah total kation yang dapat dipertukarkan pada permukaan koloid bermuatan negatif. Nilai KTK pada tanah tercemar termasuk tinggi dikarenakan tingginya kandungan $\mathrm{Ca}$ dan $\mathrm{Mg}$ akibat pengaruh limbah padat Lime mud. Kation-kation $\mathrm{Ca}$ dan $\mathrm{Mg}$ pada larutan tanah dapat meningkatkan kejenuhan basa dan meningkatkan nilai KTK-tertukar (Nazari, 2012).

Faktor kondisi tanah berpengaruh secara nyata terhadap kandungan C-organik, dimana perlakuan pada tanah tercemar (T2) memiliki kandungan $\mathrm{C}$-organik rendah jika dibanding dengan tanah tidak tercemar. Rendahnya nilai C-organik pada tanah tercemar (T1) salah satunya disebabkan karena terdapat timbunan limbah padat Lime mud. Penimbunan limbah padat Lime mud menyebabkan berkurangnya populasi dan keragaman tanaman yang dapat tumbuh di lahan tersebut. Hal ini menyebabkan mikroorganisme semakin berkurang baik dalam jumlah maupun keragaman. Menurut Hanafiah (2014) bahan organik dapat berasal dari sisa-sisah hewan serta residu tanaman seperti akar, batang 
maupun daun gugur. Faktor jenis pupuk berpengaruh nyata terhadap kadar C-organik pada tanah tercemar (T2). Hal ini menunjukkan penambahan pupuk kandang dapat meningkatkan kandungan C-organik dalam tanah. Dekomposisi bahan organik terjadi secara bertahap, dan hasil akhir proses dekomposisi berupa energi yang dibebaskan secara enzimatik berupa energi panas dan hasil akhir sederhana berupa senyawa sederhana dan kation-kation yang tersedia untuk tanaman.

Bahan organik selain meningkatkan ketersediaan karbon dalam tanah juga dapat meningkatkan kandungan P-tersedia dalam tanah. Peningkatan P-tersedia dapat terjadi secara langsung melalui proses mineralisasi atau secara tidak langsung dengan membantu pelepasan $\mathrm{P}$ yang terfiksasi. Proses mineralisasi bahan organik akan melepaskan P mineral dalam bentuk PO43-. Proses dekomposisi bahan organik akan menghasilkan asam-asam organik dimana asam-asam organik tersebut akan melepas jerapan P sehingga dapat tersedia bagi tanaman. Tanah tercemar banyak mengandung $\mathrm{Ca}$ akibat dari limbah padat Lime mud, sehingga ketersedian P menjadi rendah karena terjerap oleh $\mathrm{Ca}$. Penambahan pupuk kandang pada tanah alkali dapat melepas $\mathrm{CO} 2$ sebagai hasil dari dekomposisi bahan organik mengakibatkan kelarutan P meningkat melalui reaksi berikut :

$\mathrm{CO} 2+\mathrm{H} 2 \mathrm{O}======>\mathrm{H} 2 \mathrm{CO} 3$

$\mathrm{H} 2 \mathrm{CO} 3+\mathrm{Ca} 3(\mathrm{PO} 4) 2======\mathrm{CaCO} 3+\mathrm{H} 2 \mathrm{PO} 4-$

Reaksi diatas menunjukkan bahwa pelepasan $\mathrm{CO} 2$ sebagai hasil dari proses dekomposisi bahan organik selanjutnya akan terhidrolisis oleh air menjadi $\mathrm{H} 2 \mathrm{CO} 3$. $\mathrm{H} 2 \mathrm{CO} 3$ selanjutnya akan bereaksi dengan $\mathrm{Ca} 3(\mathrm{PO} 4) 2$ sehingga terjadi proses pelepasan ion ortophospat (H2PO4). Perlakuan pupuk kandang dan pupuk SP-36 pada tanah tercemar menunjukkan nilai P-tersedia tertinggi, hal ini menunjukkan bahwa bahan organik dapat menyediakan hara $\mathrm{P}$ melalui pelepasan ikatan $\mathrm{Ca}-\mathrm{P}$, selain itu perlakuan pupuk SP-36 meningkatkan P-tersedia dalam tanah.

Fosfat di dalam tanah dapat berbentuk organik dan anorganik. Fosfat organik berasal dari bahan organi sedangkan fosfat anorganik berasal dari mineral-mineral yang mengandung fosfat. Mikroorganisme pelarut fosfat mensekresi sejumlah asam organik, meningkatnya asam-asam organik tersebut diikuti dengan penurunan $\mathrm{pH}$ tanah. Perubahan $\mathrm{pH}$ tanah berpengaruh terhadap ketersedian hara. Asam-asam organik yang dihasilkan oleh mikroorganisme pelarut fosfat kemudian akan beraksi dan berikatan dengan pengikat fosfat seperti $\mathrm{Al} 3+, \mathrm{Fe} 3+, \mathrm{Ca} 2+$, atau $\mathrm{Mg} 2+$ membentuk khelat organik yang stabil sehingga mampu membebaskan ion fosfat terikat. Ion fosfat tersebut kemudian dapat diserap oleh tanaman.

Penambahan bahan organik meningkatkan P-tersedia dalam tanah, hal ini beraitan dengan populasi mikroorganisme tanah, dimana kandungan bahan organik yang semakin tinggi dapat meningkatkan keragaman dan populasi mikroorganisme. Salah satu mikroorganisme yang berperan dalam pelarutan Ptersedia yaitu mikroorganisme pelarut fosfat baik dari golongan fungi maupun bakteri. Menurut Alexander (1977), populasi mikroorganisme pelarut fosfat dari kelompok bakteri jauh lebih banyak jika dibanding dengan kelompok fungi. Waksman dan Starkey (1981) menambahkan, pertumbuhan mikroorganisme pelarut fosfat sangat dipengaruhi oleh kemasaman tanah. Pada tanah masam, aktivitas mikroorganisme didominasi oleh kelompok fungi sebab pertumbuhan fungi optimum pada $\mathrm{pH} 55.5$, pertumbuhan fungi semakin menurun dengan meningkatnya $\mathrm{pH}$ tanah. Sebaliknya pertumbuhan kelompok bakteri lebih optimum pada $\mathrm{pH}$ sekitar netral dan meningkat seiring dengan meningkatnya $\mathrm{pH}$ tanah.

Hasil penelitian menunjukkan adanya pengaruh yang nyata interaksi kedua faktor terhadap Ca-tertukar tanah. Penambahan pupuk kandang dan SP-36 pada tanah tercemar (T2P3) mampu menurunkan kadar $\mathrm{Ca}$ tanah sebesar $49.58 \%$ jika dibanding dengan perlakuan kontrol (T2P0). Hal ini menunjukkan bahwa bahan organik selain dapat menyediakan hara $\mathrm{P}$ melalui pelepasan ikatan $\mathrm{Ca}-\mathrm{P}$ juga dapat menurunkan $\mathrm{pH}$ tanah. Pengikatan $\mathrm{Ca}$ oleh asamasam organik akan menurunkan ketersediaan $\mathrm{Ca}+$ dalam tanah, sehingga berpengaruh pada penurunan $\mathrm{pH}$ tanah (Wandruszka, 2006).
Perbaikan sifat kimia tanah berpengaruh terhadap pertumbuhan dan produksi tanaman, dimana peningkatan kadar hara akan meningkatkan pertumbuhan dan produksi tanaman. Penggunaan bahan organik berpengaruh secara nyata terhadap ketersediaan hara tanaman dan menurunkan pengaruh pencemaran dari limbah padat Lime mud. Penggunaan pupuk kandang dan pupuk Sp-36 sebagai media perbaikan sifat kimia tanah berpengaruh terhadap beberapa parameter pertumbuhan dan produksi tanaman sorghum, seperti tinggi tanaman, berat basah brangkasan, berat total biji, berat 1000 biji serta volume akar.

Faktor kondisi tanah dan interaksi kedua faktor tidak berpengaruh nyata terhadap tinggi tanaman. Pertumbuhan tinggi tanaman pada tanah tercemar dan tanah tidak tercemar menunjukkan hasil rata-rata yang tidak berbeda jauh, hal ini menunjukkan bahwa pencemaran limbah padat Lime mud tidak berpengaruh terhadap tinggi tanaman. Adapun faktor penambahan jenis pupuk menunjukkan pengaruh nyata terhadap tinggi tanaman sebagai faktor tunggal, dimana pemberian pupuk yang berbeda mempengaruhi tinggi tanaman baik pada kondisi tanah tanah tercemar maupun tanah tidak tercemar.

Tinggi tanaman sorghum pada perlakuan pupuk SP-36 pada kondisi tanah tanah tercemar (T2P2) menunjukkan nilai tertinggi yaitu $164.33 \mathrm{~cm}$. Pupuk SP-36 termasuk pupuk anorganik, dimana pupuk SP-36 dapat termineralisasi lebih cepat jika dibanding dengan pupuk organik. Pupuk SP-36 dapat menyediakan hara $\mathrm{P}$ dengan cepat setelah penambahan pada tanaman, akan tetapi Ptersedia semakin menurun dengan bertambahnya waktu akibat perubahan dari P-tersedia menjadi tidak tersedia akibat fiksasi oleh $\mathrm{Al}$ dan $\mathrm{Fe}$ pada tanah masam dan $\mathrm{Ca}$ pada tanah alkali. Proses mineralisasi phosphor membutuhkan waktu 2 hingga 4 minggu hingga dapat tersedia bagi tanaman (Moharana, 2016). P-tersedia cepat termineralisasi dari pemupukan SP-36 sehingga dapat langsung diserap tanaman untuk proses fotosintesis dan metabolisme pertumbuhan tanaman. Perlakuan pupuk SP-36 menunjukkan tanaman memiliki respon pertumbuhan lebih cepat pada awal pertumbuhannya. Adapun perlakuan penambahan pupuk kandang menunjukkan hasil tinggi tanaman yang rendah, hal ini dikarenakan pupuk kandang termasuk pupuk organik yang membutuhkan waktu relatif lebih lama agar dapat terdekomposisi dan menyediakan kation-kation yang dibutuhkan tanaman. Secara umum pupuk organik membutuhkan waktu 4 hingga 9 minggu untuk proses dekomposisi hingga siap dipenambahankan pada tanaman (Al-Baitana, 2016).

Berat kering brangkasan menggambarkan status nutrisi tanaman, dimana hasil fotosintesis berpengaruh terhadap peningkatan berat kering tanaman. Kondisi tanah yang berbeda menunjukkan hasil yang berbeda nyata terhadap berat kering brangkasan tanaman dimana nilai rata-rata berat kering brangkasan pada kondisi tanah tercemar lebih rendah jika dibanding dengan nilai rata-rata berat kering brangkasan pada tanah tidak tercemar. Hal ini dikarenakan tanah tidak tercemar mengandung karbon organik serta unsur hara dalam jumlah yang cukup untuk pertumbuhan tanaman, sehingga proses fotosintesis dan metabolisme meningkatkan berat kering tanaman (Ferdian, 2015). Adapun penambahan jenis pupuk tidak berpengaruh terhadap berat kering brangkasan pada tanah tercemar, hal ini dikarenakan pupuk yang ditambahkan pada tanah tercemar tidak dapat meningkatkan ketersediaan hara yang mencukupi untuk diserap tanaman. Penyerapan unsur hara tanaman digunakan dalam proses fotosintesis yang selanjutnya hasil fotosintesis lebih difokuskan pada pembentukan dan pengisisan biji (Pradana, 2015).

Faktor jenis pupuk berpengaruh nyata terhadap nilai berat 1000 biji. Pada kondisi tanah tercemar, nilai berat 1000 biji tertinggi terdapat pada perlakuan pupuk kandang (T2P1) yaitu 17.74 gram, sedangkan berat 1000 biji terendah terdapat pada perlakuan kontrol (T2P0) yaitu 14.20 gram. Penambahan pupuk organik dapat meningkatkan berat 1000 biji, hal ini dikarenakan bahan organik mengoptimalkan penyerapan unsur hara oleh akar. Penambahan unsur hara fosfor dapat meningkatkan berat biji, hal ini dikarenakan fosfor merupakan bagian integral tanaman yang berperan dalam penangkapan ADP (adenosine diphosphate) atau ATP (adenosine triphosphate) yang dipakai untuk menjalankan 
reaksi-reaksi yang memerlukan energi, seperti pembentukan sukrosa dan tepung (Sitepu, 2015).

\section{KESIMPULAN}

1. Kombinasi pupuk kandang dan pupuk SP-36 pada tanah tercemar dapat menurunkan $\mathrm{pH}$ tanah sebesar dari 8.31 m3najdi 8.17 dan nilai Ca-tertukar menurun sebesar 49,58 $\%$ dibanding kontrol, serta terjadi peningkatan P-tersedia sebesar $92.89 \%$ dibanding kontrol.

2. Penambahan pupuk kandang sapi pada tanah tercemar mampu meningkatkan C-organik sebesar $222.72 \%$ dan berat 1000 biji meningkat $24,92 \%$ dibanding kontrol.

3. Pemberian pupuk SP-36 pada tanah tercemar dapat meningkatkan KTK tanah sebesar $3.25 \%$ dan tinggi tanaman meningkat 9.31 dibanding kontrol.

\section{DAFTAR PUSTAKA}

Al-Baitana, B. B., T. M. Young dan E. Ranieri. 2016. Effects of compost age on the release of nutrients. Soil and Water Conservation Research. 4:230-236

Armstrong, Donald L. 1999. Better Crops With Plant Food. Potash \& Phosphate Institute (PPI). 83(1):1-40

Alexander, M. 1977. Introduction to Soil Mycrobiology. 2nd Ed. John Wiley and Sons. New York. 467 p.

Butchee, K., D. B. Arnall, A. Sutradhar, C. Godsey, H. Zhang dan C. Penn. 2014. Determining Critical Soil pH for Grain Sorghum Production. International Journal of Agronomy. Article ID 130254

Ferdinan, B., Sunyoto, A. Karyanto dan M. Kamal. 2015. Akumulasi Bahan Kering beberapa Varietas Tanaman Sorghum (Sorghum Bicolor (L.) Moench) Ratoon tada Kerapatan Tanaman Berbeda. Agrotek Tropika. 3(1):41-48

Gaskin, J., W. Miller and L. Morris. 2017. Land Application of Pulp Mill Lime mud. Bulletin 1249. University of Georgia, College of Agriculture and Environmental Sciences, Cooperative Extension Service along with the Pollution Prevention Assistance Division

Hanafiah, Ali Kemas. 2005. Dasar-Dasar Ilmu Tanah. Jakarta : PT. Rajagrafindo Persada.

Maryati, Nelvia dan E. Anom. 2014. Perubahan Sifat Kimia Tanah Sawah saat Serapan Hara Maksimum oleh Padi (Oryza Sativa L.) setelah Penambahan Campuran Kompos Tandan Kosong Kelapa Sawit (Tkks) dengan Abu Boiler. Jom Faperta. 1(1):1-14

McCauley, Ann, C. Jones dan K. O. Rutz. 2008. Soil pH and Organik Matter. Nutrient Management. 8:1-16

Nazari, Y. A., Soemarno dan L. Agustina. 2012. Pengelolaan Kesuburan Tanah Pada Pertanaman Kentang dengan Penambahan Pupuk Organik dan Anorganik. Indonesian Green Technology. 1(1):7-12

Pradana, G. B. S., T Islami dan N. E. Suminarti. 2015. Kajian Kombinasi Pupuk Fosfor dan Kalium pada Pertumbuhan dan Hasil Dua Varietas Tanaman Sorghum (Sorghum bicolor (L.) Moench). Produksi Tanaman. 3(6):464-471.

Siregar, P., Fauzi dan Supriasi. 2017. Pengaruh Pemberian Beberapa Sumber Bahan Organik dan Masa Inkubasi
Terhadap Beberapa Aspek Kimia Kesuburan Tanah Ultisol. Agroekoteknologi. 5(2):256-264

Sitepu, L., Elza Zuhry, Nurbaiti. 2015. Aplikasi Beberapa Dosis Pupuk Fosfor untuk Pertumbuhan dan Produksi Beberapa Varietas Sorgum (Sorghum bicolor (1.) Moench). Jom Faperta. 2(2):1-12

Talukdar, D. Kumar. 2015. A Study of Paper Mill Lime Sludge for Stabilization of Village Road Sub-Base. International Journal of Emerging Technology and Advanced Engineering. 5(2):389-393

Waksman, S.A. and R.L. Starkey. 1981. The Soil and The Microbe. John Wiley and Sons, Inc. New York.

Wandruszka, Ray Von. 2006. Phosphorus retention in calcareous soils and the effect of organik matter on its mobility. Geochemical Transactions. 7(6):1-8

Yuliana, E. Rahmadani dan I. Permanasari. 2015. Penambahan Pupuk Kandang Sapi dan Ayam Terhadap Pertumbuhan dan Hasil Tanaman Jahe (Zingiber Officinale Rosc.) di Media Gambut. Agroteknologi. 5(2):37-42 